\title{
Eye and renal complication in pediatric patients with diabetes mellitus type 1
}

\author{
Nguyen Tran Ngoc Hieu*, Bui PhuongThao², Vu Chi Dung ${ }^{2}$, Nguyen Ngoc Khanh², Can Thi Bich Ngoc ${ }^{2}$, \\ Nguyen Thi Hoan ${ }^{2}$, Nguyen Phu Dat ${ }^{3}$, Truong Ngoc Duong ${ }^{1}$ \\ From 8th APPES Biennial Scientific Meeting \\ Darwin, Australia. 29 October - 1 November 2014
}

Management and life expectancy for patients with diabetes mellitus type 1 (DM 1) is significantly improved. Long-term complication of the disease such as eye and renal complication have been paid much attention because it is an important cause of blindness and renal failure.

\section{Aims}

We studied status of eye and renal complication and its relationship with $\mathrm{HbA} 1 \mathrm{C}$ in 81 patients diagnosed of DM 1.

\section{Method}

Observational, random collection.

\section{Results}

Eye complication was seen in $23.5 \%$ of patients. Renal complication was seen in $22.2 \%$ of patients. $13.6 \%$ of patients had both kinds of complication. The longer duration of DM 1 the patients had, the more eye and renal complication was detected. In groups with eye and renal complication, HbA1c was significantly higher than that in groups without complication. Probability of having renal complication in a poor glucose control group was higher than that in a good glucose control group with OR ratio of 2.2. For eye complication, the figure was 3.7.

\section{Conclusion}

The best thing to postpone eye and renal complication is glucose control.

\section{Authors' details}

${ }^{1} 103$ Military Hospital, Hanoi, Vietnam. ${ }^{2}$ Vietnam National Hospital of Pediatrics, Hanoi, Vietnam. ${ }^{3}$ Hanoi Medical University, Hanoi, Vietnam.

Published: 28 April 2015

doi:10.1186/1687-9856-2015-S1-P23

Cite this article as: Hieu et al:: Eye and renal complication in pediatric patients with diabetes mellitus type 1. International Journal of Pediatric Endocrinology 2015 2015(Suppl 1):P23.

${ }^{1} 103$ Military Hospital, Hanoi, Vietnam

Full list of author information is available at the end of the article

Submit your next manuscript to BioMed Central and take full advantage of:

- Convenient online submission

- Thorough peer review

- No space constraints or color figure charges

- Immediate publication on acceptance

- Inclusion in PubMed, CAS, Scopus and Google Scholar

- Research which is freely available for redistribution
C Biomed Central 